\title{
講演音声の音声的特徵とその印象に対する評価構造モデル
}

\author{
山住 賢司 ${ }^{1)}$, 籠宮 隆 $2^{2)}$, 槙 洋 - ${ }^{3)}$, 前川 喜久雄 ${ }^{4)}$ \\ ${ }^{(1)}$ 東京都立大学人文科学研究科, ${ }^{2}$ 神戸大学総合人間科学研究科, \\ ${ }^{3)}$ 北海道大学文学研究科, ${ }^{4)}$ 国立国語研究所研究開発部門)
}

\section{The evaluation structure model of the relationship between impression ratings and speech properties in public speaking}

\author{
${\text { Kenji } \text { Yamasumi }^{1)} \text {, Takayuki Kagomiya }}^{2)}$, Yohichi Makis ${ }^{3)}$, Kikuo Maekawa ${ }^{4)}$ \\ ${ }^{1)}$ Graduate School of Humanities, Tokyo Metropolitan University \\ ${ }^{2)}$ Graduate School of Cultural Studies and Human Science, Kobe University \\ ${ }^{3)}$ Graduate School of Letters, Hokkaido University \\ ${ }^{4)}$ National Institute for Japanese Language
}

\begin{abstract}
We analyzed the relationships between impression ratings and phonetic properties of monologues using the Corpus of Spontaneous Japanese (CSJ). The impression ratings were of subjective attributes such as speaking rate and speech style. Each attribute was rated on a seven-point scale. The phonetic properties were objective attributes such as speaking rate and pause ratio, as measured directly from the CSJ speech data. Using six phonetic properties and five impression ratings as variables, structural equation modeling was conducted to explain not only the relations between the impression and phonetic properties but also the relations among the impressions. The model showed that the impressions "Skillfulness" and "Liking" could be predicted from the impressions "Speech rate", "Activity", and "Formality", which in turn could be related with the objective phonetic properties. Moreover, it was shown that the higher the "Skillfulness" evaluation, the higher the "Liking" evaluation.
\end{abstract}

(Received 3 October 2006, Accepted 27 November 2006)

Keywords: impression rating 印象評定, speech property 音声特徴, structured equation modeling 構 造方程式モデリング, the corpus of spontaneous Japanese 日本語話し言葉コーパス

\section{1.はじめに}

音声言語は我々がコミュニケーションに用いる最も 一般的なツールであり, その知覚・認知についての研 究は心理学・音声学・音声工学など様々な分野で広く 行われてきている．言語的コミュニケーションにおい て，音声によりその言語的情報が伝達されるのみなら ず，非言語的な情報も音響的特徵の中に鳁み込まれて 伝達されている，例えば，「怒り」や「悲しみ」と いった話者の感情状態が聞き手に伝わったり，「上手
い」話し方や「速い」話し方などといった印象を与え る要素が伝達されている。 そういった非言語的情報に ついては，まだ言語を獲得していない新生児や乳児に おいても, 声のピッチやテンポ・抑揚といった非言語 情報に対する処理能力が存在することが示唆されてお り（斉藤他, 2005), 音声コミュニケーションにおけ る基本的な要素であると考えられる.

そのような音声言語の音声的特徵と, その音声から 受ける印象との関係に着目した研究は近年増えつつあ 
る. Murray \& Arnott (1993) は感情音声の音声的 特徴についてまとめており，木戸他（2002）は通常発 話における声質表現語と音響関連量との関係を調査し, 重野（2004）は感情表現された音声についての認知と 音響的性質との間の対応関係を検討している.

しかしながら,これまでの研究においては単語や短 文といった比較的短い音声を対象として研究がなされ てきた点が指摘されよう。単語や短文レベルで伝達さ れる印象も確かに存在するであろうが, 発話全体から 受ける総体的な印象というものもまた存在するであろ う. 例えば,「発話の速さ感」のような印象は短い音 声によってもある程度判断できるような印象であるだ ろうが,「上手さ」や「好ましさ」といった印象につ いては，ある程度の長さを持った音声により明確に受 け止められる印象であると考えられる。また日常場面 において，そのような短い要素だけでコミュニケー ションが完結することはまれであり, 現実場面に則っ た研究の進展が今後必要となってくるであろう.

Erickson（2005）が指摘するように, 音声処理技術 の発展や音声コーパスの整備・増加により上記の問題 は解消されつつある。特に『日本語話し言葉コーパ ス』（前川，2004）は約 660 時間におよぶ講演音声を 主とする自発音声のデータベースであり, 約 3300 ファイルの音声信号が収録されると共に, 各音声の転 記テキストや韻律情報・形態論情報といった豊富な研 究用情報が付随している. 自発音声の自動認識や音声 合成といった音声情報処理学的研究に利用出来るだけ の豊富なデー夕量と, 音声学や言語学的研究に利便性 のある多様な付加情報を兼ね備えているのが特徵であ る.『日本語話し言葉コーパス』に収録されている講 演音声は主に学会講演と模擬講演の 2 種に大別される. 学会講演の音声は, 工学系・人文社会系の種々の学会 における研究発表をその場で録音したもので, 各講演 の長さは 10〜25 分程度のものから 1 時間に及ぶもの まである．模擬講演の音声は, 年齢と性別のバランス を取った一般話者による日常的な話題についてのス ピーチを録音したもので, 10〜15 分程度のものである. 学会講演・模擬講演ともに講演全体の音声が収録され ており,『日本語話し言葉コーパス』は現実場面に近 い形での生態学的妥当性を満たす音声デー夕を提供し てくれる。このようなデータベースの存在により, あ る程度の長さを持った音声から受ける全体的な印象と いったものについての研究が可能となってきている.

また, 先行研究においては, 特定の 1 つの印象と音
声的特徵との関係をみるにとどまっており，全体とし て種々の印象がどう関係しており，それらと音声的特 徵がどのように結びついているのかは検討されていな い. 人がどのような発話に対してどのような印象を受 けるのかを明らかにする上で, 音声特徴のあるパラ メータが異なる複数の印象に対して，それぞれどのよ うな影響を及ぼすのかを知ることも重要である.

そこで今回の研究では上記の点について『日本語話 し言葉コーパス』に収録された音声データならびに印 象評定デー夕を用い, 自発的に発話された講演音声の 音声的特徵とその印象評定に対する因果モデルを構築 し, 講演音声における印象評価構造がどのようなもの であるかを明らかにすることを目的とする.

\section{2. 方法}

本論文では『日本語話し言葉コーパス』に付随する 印象評定デー夕を用いて分析を行った。 今回分析の対 象としたのは，その中でも著者らがデー夕収集作業を 行った「集合評定デー夕」と呼ばれる印象評定デー夕 である.そこで以下に『日本語話し言葉コーパス』に おける「集合評定デー夕」がどのように収集されたも のであるかを簡単に説明する，なお，『日本語話し言 葉コーパス』に付随する印象評定デー夕については, 籠宮他（2004）に詳細が記載されている.

\section{1 音声デー夕}

『日本語話し言葉コーパス』の「コア」と呼ばれる 約 50 万語分のデータセット（『日本語話し言葉コーパ ス』全体では約 750 万語）に含まれる音声のうち，独 話の講演音声 177 を印象評定の対象音声とした。「コ ア」に相当する音声に対しては, 通常付与される情報 に加えて,さらに多様かつ精密な研究用情報が付与さ れている，例えば，言語音研究等に利便性のある分節 音ラベルや韻律ラベルなどの情報が付与されている. 「集合評定デー夕」と呼ばれる印象評定デー夕もまた, 様々な研究上の利便性を増すために付与されたもので ある. 表 1 に今回の分析で用いた「コア」に含まれる 独話の講演音声の種別を示す.

印象評定にあたっては，講演の全音声を聞かせるの ではなく, 各講演の時間的に「冒頭」「中盤」「終盤」 それぞれ 1 分程度の内容的にまとまりのある部分を抜 き出し, 聴取単位とした。講演の全音声ではなく部分 を聞かせる理由としては, 各講演音声は 10 分から 15 分程度の比較的長いものであるため全てを聞かせた場 合, 評定者の疲労や集中力低下の恐れがあったためで 
表 1 「コア」に含まれる独話の講演音声の種別

\begin{tabular}{l|r}
\hline \hline 講演音声の種類 & 数 \\
\hline 工学系学会講演 & 49 \\
人文社会系学会講演 & 22 \\
模擬講演 & 106 \\
\hline 合計 & 177 \\
\hline
\end{tabular}

ある。また同時に，長い講演音声の中で，どの部分に 対する印象であるのかという点を明確にするためでも ある.

これらの音声とは別に，評定者が行った評定の一貫 性を確認するために, 同一音声を 2 回評価するものを 『日本語話し言葉コーパス』に収録されているコア以 外の講演音声データから 2 音声選んで加えた。これら 2 つの音声は, 工学系学会講演と人文社会系学会講演 から各 1 音声ずつ選出された. この一貫性確認のため の音声データも「冒頭」部分の 1 分程度のまとまりの ある部分を抜き出し，聴取単位とした。これらの同一 音声に対する評価が著しく異なっている場合, その評 定者の評価には一貫性がないと判断し評価データとし て使用しなかった。

2.2 評定者

人材派遣会社を通じて集めた 20 代男性・ 20 代女 性·50 代男性・50 代女性それぞれ 5 名ずつの計 20 名 を評定者とした。いずれも過去に音声学・言語学・心 理学に関する仕事に従事したことのないものであった. 特定の年代や性別に偏った評定データではなく，ある 程度の幅をもった年代の評定を得るためにこのよう な年代・性別の評定者を選定した.

\section{3 評定尺度}

自発的な音声, 特に講演音声の印象を「話し方の特 徴」という観点から総合的に捉えるための尺度である 『講演音声評定尺度』（山住他, 2005）が用いられた。 この尺度は, 表 2 に示すとおり対語形式の 20 項目か らなっている. 講演音声評定尺度は 4 項目から成る 5 つの下位尺度（「好悪」「上手さ」「速さ感」「活動性」 「スタイル」）を含んでいる。各項目は 7 段階で評定を 行ったので, それぞれ 1〜 7 までの得点を与え数值化 した。よって各下位尺度は 4〜28 までの尺度得点を取 ることになる。

2.4 実施方法

印象評定は個人法で行われた。音声刺激の呈示と印
表 2 講演音声評定尺度

\begin{tabular}{ll}
\hline \hline 好悪 & \\
心地よいー不快な & 感じの良いー感じの悪い \\
好きなー嫌いな & 親しみやすいー親しみにくい \\
\hline 上手さ & \\
なめらかな-しどろもどろな & 流暢なーたどたどしい \\
話し慣れたー話し慣れていない & 上手いー下手な \\
\hline 速さ感 & \\
速いー遅い & スピード感のある-ゆったりした \\
せわしげなーのんきな & 落ち着きのないー落ち着きのある \\
\hline 活動性 & \\
力強いー弱々しい & 声の大きいー声の小さい \\
積極的なー消極的な & 元気のあるー元気のない \\
\hline スタイル & \\
まじめなーふまじめな & 礼儀正しいー無礼な \\
丁寧なーぞんざいな & 上品なー下品な \\
\hline
\end{tabular}

象評定の回答にはパーソナルコンピュータが用いられ た. 評定者ごとに項目の呈示順や語対の左右の配置・ 音声刺激の呈示順はランダムになるようにし, 刺激音 声はへッドフォンを通じて呈示された。 なお印象評定 は，刺激音声を聴き終えた後に行われた。

印象評定は，1日あたり 75 から 90 聴取単位の評定 を行い, 約 2 週間の日程で全ての評定を行った. 評定 の一貫性を確認するための音声は，この中で日をおい て 2 度呈示された.

\section{5 評定データの扱い}

評定の一貫性を確認するために含めた 2 つの聴取単 位に対する評定值間の相関係数が 0.5 未満であった 10 名のデー夕は, 評定の一貫性が保証されない恐れがあ るため採用されなかった。 したがって, 残った 10 名 の評定者 (20 代男性 3 名. 20 代女性 3 名. 50 代男性 2 名. 50 代女性 2 名）による尺度得点の平均值を印象 評定データとして用いた. 評定者数が半数となったが 評定データの信頼性という点を考えると, 一貫した評 定を行っていない評定者のデー夕を含めることは望ま しくない. 今回の分析では, 評定対象とする音声の聴 取単位数は 500 を超えるものであり, 安定した評定者 のデータを用いることで, モデルの一般化に十分な量 のデータが確保されていると考えた.

2.6 分析方法

講演音声の特徵量として, 以下のものを『日本語話 し言葉コーパス』に付随している音声データの書き起 こしテキストを用いて算出した.

・ モーラ数/秒 (聴取単位中の総モーラ数/聴取単位 中の発話時間長の総計)

- 文節数/秒 (聴取単位中の総文節数/聴取単位中の 発話時間長の総計) 
・ポーズ比（聴取単位中のポーズ総時間/聴取単位 の時間）

・ポーズ数/秒（聴取単位中の総ポーズ数/聴取単位 の時間)

- 単独の笑い数/秒（聴取単位中の単独の笑いの総 数/聴取単位の時間)

・笑いながら発話数/秒（聴取単位中の笑いながら の発話の総数/聴取単位の時間)

なおここでのポーズとは, コーパスの転記基本単位 として区切られる，200ms 以上の無音区間を指す.

講演音声の特徴量としては, 他に F0 周波数やスぺ クトル特性やフォルマント分析に基づくものなど (Boves, 1984）も考えられる. しかし本論文では「話 し方の特徵」から講演音声の特徵を捉える『講演音声 評定尺度』との関係を調べることを重視し, さらに局 所的な指標となるような音声特徵量ではなく, 上記の ような発話全体の大局的な変化を捉えるような音声特 徵量を用いることにした。 また，自発音声に特徵的な イベントとしての「笑い」に関する指標も加えた.

上記の特徴量に対し「発話量」「ポーズ」「笑い」と いう 3 つの潜在変数を仮定した. 以下にそれら 3 つの 潜在変数の内容について説明を行う.

「発話量」は, モーラ数/秒と文節数 / 秒といった, 無音時間を除いた純粋に音声が発声されている単位時 間あたりの発話量の多さに関係した観測変数に影響を 及ぼす潜在変数である。「ポーズ」は，ポーズ比や ポーズ数/秒といった発話間の無音区間の割合やその 頻度に影響を及ぼす潜在変数である。「笑い」は, 単 独の笑い数/秒や笑いながらの発話数/秒といった発 話中に生起する笑いというイベントに影響を及ぼす潜 在変数である.

これらの講演音声の特徵量に関する 3 つの潜在変数 と講演音声評定尺度の 5 つの下位尺度との関係につい て, 構造方程式モデリング (SEM : Structural Equation Modeling) による印象評価構造モデルの構築を 試みた. 構造方程式モデリングとは共分散構造分析と も呼ばれてきたもので,「構成概念や観測変数の性質 を調べるために集めた多くの観測変数を同時に分析す るための統計的方法である（豊田, 1992)」.

まずモデルを構築するにあたっては, 音声を聴き終 えてから印象評定を行うという時間的順序を重視し, 講演音声の特徵量が, 印象に影響を与えるという流れ を基本的な枠組みとして取り入れた. そして講演音声 評定尺度で測定される 5 つの下位尺度間で, お互いに

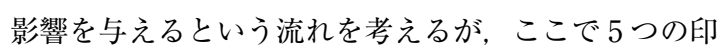
象間に階層構造を仮定することにした。

『講演音声評定尺度』は,「好悪」「上手さ」「速さ 感」「活動性」「スタイル」という５つの下位尺度から 成っており，それぞれ話し方の特徴の各側面を測定し ている。 これらの下位尺度の中で,「好悪」「上手さ」 といったものは, 他の下位尺度と比較して総合的な評 価としての側面を持ち, 上位階層にあるようなものと して考えた．籠宮他（2003）の分析において, 講演音 声の特徵量と『講演音声評定尺度』の各下位尺度との 重回帰分析を行っているが,「好悪」の尺度について の分析結果は良いものではなく, 単純に物理的な指標 と関連するものではないことが示唆されている，その ような点もふまえて, これらの尺度は特徽量からの直 接のパスによって説明されるというよりは，他の印象 からのパスによって説明されるというモデルを考えた 他の 3 つの尺度については, 音声特徴量による説明は 容易なものとして，「好悪」「上手さ」よりも下位の階 層にあるものとして考えた.

まとめると, 講演音声の特徵量により「速さ感」 「活動性」「スタイル」といった印象が影響を受け，そ れらの印象がさらに「好悪」「上手さ」といった総合 的な評価へと結びつくというモデルを仮定した，その ようなモデルに対して SAS（Ver.8.2）のCALIS プロ シジャを用い, 構造方程式モデリングを実施した.

\section{3. 結果}

表 3 に講演種別の音声特徵量の基礎等計量を, 表 4 に分析に用いた観測変数間の相関係数を示す.これら の観測変数間の相関関係をもとに, 構造方程式モデリ ングに㧍けるパラメー夕の推定を行った.

モデルの適合度（GFI・AGFI）や情報量（AIC） 等の指標を参考とし，またモデルとしての解棌可能性 という点を考慮した結果, 最終的に採択したモデルの パス図（標準化解）を図 1 に示す. パス係数は全て $5 \%$ 水準で有意となっている.

上位の階層として設定した「好悪」「上手さ」にも， 講演音声の特徵量である「ポーズ」「発話量」「笑い」 からのパスの多くが有意なものとして残った.

講演音声の特徵量を表す潜在変数間では,「ポー ズ」と「発話量」の間に負の相関関係 $(-0.32)$ が有 意なパスとして認められた。

適合度の指標は $\mathrm{GFI}=0.935, \mathrm{AGFI}=0.858$ であり, GFI と AGFI の間に若干の開きはあるもののモデル 


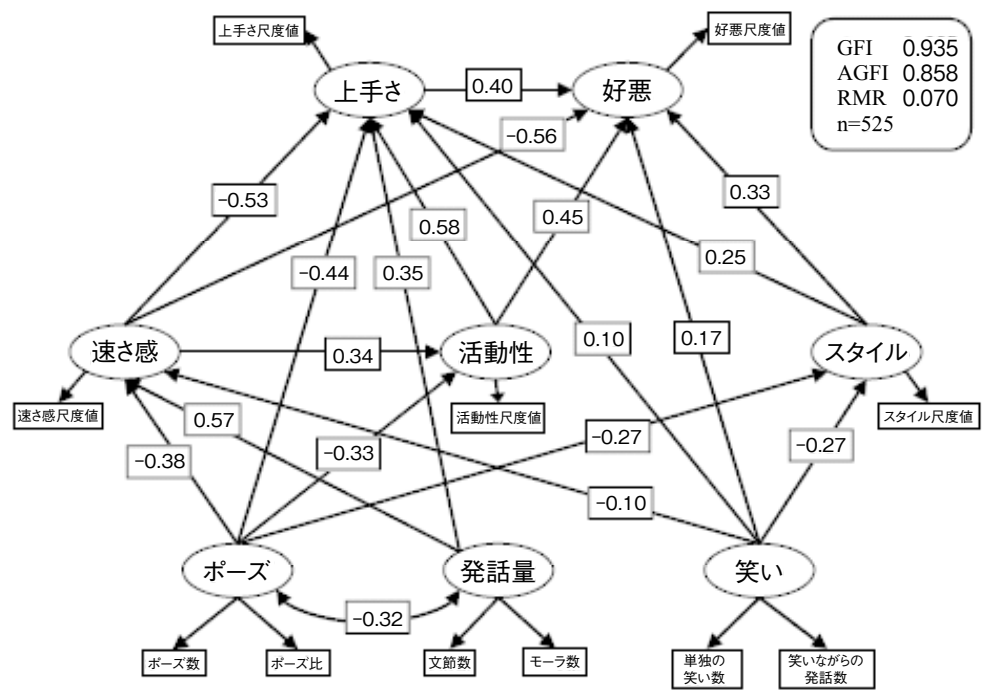

図 1 講演音声に対する印象評価構造モデルのパス困

表 3 講演種別の音声特徵量の基礎等計量

\begin{tabular}{l|c|rrrrrr}
\hline \hline & & ポーズ比 & ポーズ数 & モーラ数 & 文節数 & 笑い数 & 笑いながら数 \\
\hline 工学系学会講演 & 平均 & 0.181 & 0.355 & 9.023 & 1.868 & 0.000 & 0.000 \\
& SD & 0.060 & 0.075 & 0.798 & 0.225 & 0.003 & 0.000 \\
\hline 人文社会系学会講演 & 平均 & 0.168 & 0.369 & 8.165 & 1.733 & 0.005 & 0.001 \\
& SD & 0.065 & 0.099 & 0.709 & 0.219 & 0.016 & 0.006 \\
\hline 模擬講演 & 平均 & 0.230 & 0.403 & 7.926 & 1.827 & 0.011 & 0.003 \\
& SD & 0.080 & 0.069 & 0.830 & 0.205 & 0.019 & 0.011 \\
\hline
\end{tabular}

表 4 分析に用いた全観測变数間の相関係数行列

\begin{tabular}{|c|c|c|c|c|c|c|}
\hline & ポーズ比 & $\begin{array}{l}\text { ポーズ数 } \\
\end{array}$ & モーラ数 & 文節数 & 笑い数 & 笑いながら数 \\
\hline ポーズ比 & 1.000 & & & & & \\
\hline ポーズ数 & 0.538 & 1.000 & & & & \\
\hline モーラ数 & -0.337 & -0.273 & 1.000 & & & \\
\hline 分節数 & -0.089 & 0.015 & 0.633 & & & \\
\hline 笑い数 & 0.105 & 0.064 & -0.030 & 1.000 & 1.000 & \\
\hline 笑いながら数 & 0.070 & 0.008 & -0.089 & 0.158 & 0.525 & 1.000 \\
\hline 好㥶 & -0.253 & 0.105 & -0.086 & -0.005 & 0.108 & -0.032 \\
\hline 上手さ & -0.637 & -0.246 & 0.330 & 0.122 & -0.018 & -0.058 \\
\hline 速さ感 & -0.589 & -0.415 & 0.704 & 0.378 & -0.153 & -0.130 \\
\hline 活動性 & -0.538 & -0.222 & 0.302 & 0.109 & -0.108 & -0.146 \\
\hline \multirow[t]{2}{*}{ スタイル } & -0.295 & -0.086 & 0.111 & -0.152 & -0.260 & -0.243 \\
\hline & 好悪 & 手さ & 速已感 & 活動性 & スタイル & \\
\hline 好悪 & 1.000 & & & & & \\
\hline 上手己 & 0.659 & 1.000 & & & & \\
\hline 速さ感 & -0.191 & 0.294 & 1.000 & & & \\
\hline 活動性 & 0.447 & 0.672 & 0.527 & 1.000 & & \\
\hline スタイル & 0.429 & 0.413 & 0.150 & 0.167 & 1.000 & \\
\hline
\end{tabular}

とデータの標本共分散行列との適合に問題はないと判 断した。

\section{4. 考察}

本モデルにおいては, 講演音声特徴量を表す,「ポー ズ」, 「発話量」,「笑い」, という 3 つの潜在変数が各 印象へと影響を与えている.
「速さ感」の印象には,「発話量」と「ポーズ」の寄 与が大きく，「発話量」が多く「ポーズ」の少ない講 演音声が「速い」発話の印象へと結びついている.

「活動性」の印象には,「ポーズ」の寄与が大きくま た「速さ感」からの影響もある。すなわち「ポーズ」 が少なく「速さ感」が速い印象を持たれる講演音声で あるほど「活動性」の高い講演だという印象が強くな ることが示されている.「発話量」という講演音声特 徵量は「活動性」に対して直接のパスはないが,「速 さ感」を経由して間接的に影響を与えている.

「スタイル」には「ポーズ」と「笑い」が影響を与 え, 両者が少ないものほどあらたまった発話という印 象が高まる.

「上手さ」の印象に対しては，これまで見てきた 「速さ感」「活動性」「スタイル」といった印象からの 影響を受ける。「速さ感」が速くなく「活動性」が高 く「スタイル」のあらたまった発話によって,「上手 い」発話という印象が高まる. また, 講演音声特徴量 からの影響もあり，「ポーズ」の少なさと「発話量」 の多さが「上手さ」の印象に寄与している.

ところで「速さ感」の印象は直接的には速くなるほ ど「上手さ」の印象を低下させるが,「活動性」を経 由した間接効果でみてみると「速さ感」が上昇するこ とで「活動性」の印象が高まり，それによって「上手 さ」の印象が上昇する。この間接効果の大きさは 0.34 （速さ感から活動性へのパスの因果係数） $\times 0.58 （$ 活 
動性から上手さへのパスの因果係数） $=0.20$ と直接効 果の- 0.53 と比べると小さいものの, ある程度の「速 さ感」が「上手さ」の印象を押し上げるという関係が 現れている.

「好悪」の印象では,「上手さ」の印象が高い音声ほ ど「好まれる」話し方の講演であるという関係が示さ れた。また「速さ感」が速くなく「活動性」が高く 「スタイル」のあらたまった発話の印象も,「好悪」の 印象を高める要因となっている。「活動性」を経由し た「速さ感」の間接効果に関しては「上手さ」で見ら れたのと同様の関係であるが, こちらは 0.34 (速さ感 から活動性へのパスの因果係数） $\times 0.45$ (活動性から 好悪へのパスの因果係数） $=0.15$ と小さく,「好悪」 の印象に与える影響は少ない.

本モデルでは，「上手さ」「好悪」といった総合的な 評価の印象は，どちらも「速さ感」が速くなく「活動 性」が高く「スタイル」があらたまっている印象に よって上昇する関係が示されている。 そして「上手 い」話し方という印象を持たれる講演は, さらに「好 まれる」話し方の講演だという印象が強まるというこ とが示された。それらの印象に対しては，「ポーズ」 や「発話量」からの直接のパスもあるが，その因果係 数の值はいずれも他の印象からのパスの因果係数の值 よりも小さなものとなっている. 従って,「上手さ」 や「好悪」の印象は, 直接「ポーズ」や「発話量」の ような物理的特徴との対応で説明するよりも, それら によって形成される「速さ感」や「活動性」といった 印象によってより良く説明される, 認知的・総合的な 印象として捉えられることを本モデルは示している.

本モデルでは, 講演音声特徴量が各印象に異なる程 度で寄与する関係も示されている。「ポーズ」の少な さは「速さ感」「活動性」「スタイル」の印象を同程度 に高める一方,「ポーズ」と負の相関関係のある「発 話量」は増加し,「発話量」の多さは「速さ感」の印 象を高めている。「ポーズ」の少なさは「上手さ」の 印象を高めるが,「ポーズ」の少なさ・「発話量」の多 さによって高まる「速さ感」の印象は逆に「上手さ」 の印象を低下させるという関係になっており, 適度な 速さ感が求められる関係となっている。また「笑い」 の多さは「好悪」の印象を高めるが, 同時に「スタイ ル」の印象を低下させ，そのことにより「好悪」の印 象を低下させる要因にもなっている. このように本モ デルでは, 重回帰分析のような個々の印象と音声特徵 との関係を調べるだけでは見ることの出来ない, 音声
特徵量と印象との複雑な関係を見てとることが可能と なっている.

\section{5. まとめ}

本研究では, 『日本語話し言葉コーパス』に収録さ れた講演音声の印象評定データを元に構造方程式モデ リングを行い, 講演音声に対する印象評価構造モデル の構築を行った。 その結果, 講演音声の音声的特徵で ある「発話量」「ポーズ」「笑い」と，「好悪」「上手 さ」「速さ感」「活動性」「スタイル」といった講演音 声の話し方の印象との関係, 並びに印象間の関係を明 らかにした．特に「上手さ」「好悪」といった印象は 講演音声特徵量によって規定される「速さ感・活動 性・スタイル」といった印象から形成される総合的な 評価であるという関係が示された。 また「上手さ」の 印象が高いほど,「好悪」の印象が高まる関係である ことが示された.

今後はこのモデルで見られた関倸が, 音声特徵のパ ラメータを実際に操作した時にも見られるかどうか, 音声再合成による実験的検討を行ない, 今回の印象評 価構造のモデルの妥当性を検討していく予定である.

\section{引用文献}

Boves, L. (1984) The Phonetic Basis of Perceptual Ratings of Running Speech, Foris Publications, U. S.A.

Erickson, D. (2005) Expressive Speech : Production, perception and application to speech synthesis. Acoustical Science and Technology, 26, 317-325.

籠宮隆之, 山住賢司, 槙洋一, 前川喜久雄 (2003) 講 演音声評定尺度を用いた音声評定の分析，日本音響 学会 2003 年秋季研究発表会講演論文集, 369-370.

籠宮隆之, 山住賢司, 槙洋一（2004）印象評定デー夕 の概要, 『日本語話し言葉コーパス』付属文書, 国 立国語研究所.

木戸博, 箕輪有希子, 粕谷英樹（2002）声質表現語の 音響関連量に関する非線形分析－決定木による方法 -, 日本音響学会誌, 58, 586-588.

前川喜久雄 (2004) 『日本語話し言葉コーパス』の概 要, 日本語科学, 15, 111-133.

Murray, I. R., Arnott, J. L. (1993) Toward the simulation of emotion in synthetic speech : A review of the literature on human vocal emotion. Journal of the Acoustic Society of America, 93, 1097-1108. 


\section{日本官能評価学会誌 Vol. 11 No. 1}

斉藤由里, 近藤武夫, 青山志緒里, 福本理恵, 小林雅 夫，利島保（2005）新生児における声の抑揚に対す る脳血流反応, 日本心理学会第 69 回大会発表論文 集, 1176.

重野純（2004）感情を表現した音声の認知と音響的性 質, 心理学研究, 74, 540-546.
豊田秀樹（1992）SASによる共分散構造分析, 東京 大学出版会, 東京.

山住賢司, 籠宮隆之, 槙洋一, 前川喜久雄（2005）講 演音声の印象評価尺度, 日本音響学会誌, 61, 303311. 